\title{
Farklı genetik kaynaklardan elde edilen F2 biber genotiplerinde (Capsicum annuum L.) TSWV'ye dayanıklılığın moleküler analizi
}

\section{Molecular screening for TSWV resistance in F2 pepper (Capsicum annuum L.) genotypes from different genetic background}

\author{
Hatice İKTEN \\ Akdeniz Üniversitesi, Ziraat Fakültesi, Tarımsal Biyoteknoloji Bölümü, 07070, Antalya, Türkiye \\ Sorumlu yazar (Corresponding author): H. İkten, e-posta (e-mail): haticeikten@akdeniz.edu.tr
}

\section{MAKALE BILLGISİ}

Alınıs tarihi 28 Aralık 2018

Düzeltilme tarihi 22 Ocak 2019

Kabul tarihi 22 Ocak 2019

\section{Anahtar Kelimeler:}

$\mathrm{F} 2$

TSWV

CAPS marker

ko-dominant marker

MAS

\begin{abstract}
ÖZ
TSWV'ye dayanıklılık geni ile ilişkili olan SCAC $_{568}$ CAPS markırı ıslah programlarında dayanıklı ve hassas biber genotiplerini ko-dominant seviyede (RR, $\mathrm{Rr}$, rr) ayırt etmek için kullanılmaktadır. Ancak farklı genetik arka plana sahip olan bazı 1slah materyallerinin heterozigot ve homozigot düzeyde seleksiyonunda tutarsız sonuçlar alınabilmektedir. $\mathrm{Bu}$ çalışmada farklı genetik kaynaklardan elde edilmiş F2 biber genotiplerinin $\mathrm{SCAC}_{568}$ markın kullanarak domates lekeli solgunluk virüsü (TSWV)'ne karşı dayanıklılığının moleküler yöntemlerle testlenmesinde iki farklı enzimle (XbaI ve TaqI) yapılan kesim sonuçlarının karșılaştırmalı olarak birlikte değerlendirilmesinin ve dayanıklı ile hassas genotiplerin kodominant seviyede belirlenmesinde kullanılabilirliğinin test edilmesi amaçlanmıştır. Çalışmada F2 aşamasındaki iki popülasyona ait genotipler SCAC $_{568}$ CAPS markır kullanılarak test edilmiştir. Çalışmada her iki popülasyondan toplam 110 adet F2 bitkisine ait genomik DNA SCAC $_{568}$ CAPS markırı ile PCR'da çoğaltılmış ve elde edilen PCR ürünleri XbaI ya da TaqI enzimleri ile kesilmiștir. Kesim ürünleri \% 2'lik agaroz jelde ayrıștırılarak UV altında görüntülenmiştir. Çalışma sonuçlanı popülasyonlardan bir tanesine ait F2 genotiplerinde heterozigot ve homozigot düzeyde beklenen genotipik aç1lımı (1RR:2Rr:1rr) verirken diğer popülasyonda F2 seviyesinde beklenen açılımın elde edilebilmesi için her iki enzime ait kesim sonuçlarının birlikte değerlendirilmesi sonucu dayanıklı ve hassas bireylerin heterozigot ve homozigot seviyede ayırt edilebileceğini göstermiştir. Sonuçlar açılım gösteren F2 popülasyonlarında $\mathrm{SCAC}_{568}$ CAPS markırının TSWV'ye karş1 hassas ve dayanıklı genotiplerin belirlenmesinde, iki enzimle kesim yapılarak başarılı bir şekilde kullanılabileceğini teyit etmiştir.
\end{abstract}

\section{ARTICLE INFO}

Received 28 December 2018

Received in revised form 22 January 2019 Accepted 22 January 2019

\section{Keywords:}

F2

TSWV

CAPS marker

codominant marker

MAS

\begin{abstract}
A CAPS marker linked to resistance gene to TSWV in pepper was employed to classify tolerant and susceptible plants at co-dominant level (RR, Rr, rr). During this process selecting heterozygote and homozygote resistant plants from different genetic backgrounds may show some deviations. In this experiment for determination of heterozygote/homozygote resistance/susceptible genotypes developed from different genetic background using two enzymes (XbaI and TaqI) separately at the same time and assessing the gel pictures together was studied. For this purpose, the F2 pepper plants belonging to two different population and each population developed from different genetic background were tested with $\mathrm{SCAC}_{568}$ marker. The genomic DNA of 110 plants representing both populations were amplified with SCAC568 CAPS marker and the PCR products were digested with XbaI and TaqI enzymes. The digested fragments were separated in agarose gel and visualized under UV light. The genotypes belonging to one population gave the expected segregation (1RR: 2Rr: 1rr) at F2 level while the other population required digestion of PCR products with both XbaI and TaqI enzyme separately and assessment the results together to determine resistant and susceptible plants at co-dominant level and to obtain the expected F2 segregation. The results showed that SCAC568 CAPS marker can be used successfully to select the resistant and susceptible genotypes in F2 segregation population by employing two enzymes.
\end{abstract}




\section{Giriş}

Domates lekeli solgunluk virüsü (TSWV) dünyada biber üretimini sınırlayan ve ekonomik kayıplara neden olan en önemli ilk on virüs arasında yer almaktadır (Goldbach ve Peters 1994; Parrella 2003). TSWV ilk defa Avustralya'da Brittlebank (1919) tarafindan rapor edilmiş olup domates, biber, marul, patates, papaya, yerfistığı tütün gibi çok çeşitli konukçusu bulunmaktadır (German ve ark. 1992; Parrella ve ark. 2003). Türkiye'de ilk defa marul bitkisinde Tekinel ve ark. (1969) tarafindan tespit edilen TSWV daha sonra domates (Tekinel 1973), tütün (Azeri 1994) ve biberde de (Yürtmen ve ark. 1999) tespit edilmiştir. TSWV'nin neden olduğu ürün kayıplarını en aza indirmek için farklı kontrol metotları uygulanmaktadır. Vektörle mücadelede kullanılan fiziksel, kimyasal ve biyolojik metotlar hem uygulaması güç hem de genellikle yetersiz kalmaktadır (Rosello ve ark. 1996; Cebolla-Cornejo ve ark. 2003). Bu nedenle mücadelede en iyi yöntemin TSWV'ye dayanıklı çeşit geliştirmek olduğu belirtilmektedir (Floor 1971). Dayanıklı çeşit geliştirme çalışmalarında uygulanan klasik testleme zaman ve işgücü kaybına neden olan zahmetli bir yöntemdir (Moury ve ark. 2000). TSWV'ye dayanıklılığ 1 kontrol eden gen (Tsw) birçok Capsicum chinense biber genotipinde ('PI 152225', 'PI 159236', 'CNPH 275' 'C00943've '7204') tespit edilerek 10. kromozomda haritalanmış ve kültür çeşitlerine (Capsicum annum) aktarılmıştır (Black ve ark. 1991; Costa ve ark. 1995; Boiteux 1995; Moury ve ark. 1997; Jahn ve ark. 2000). TSWV'ye dayanıklılık geninin (Tsw) islah çalışmalarında kullanımını kolaylaştırmak için Moury ve ark. (2000) tarafindan yürütülen çalışmada $T s w$ 'ye bağlı olduğunu tespit edilen RAPD (Rastgele çoğaltılmış polimorfik DNA) markırı, CAPS (kesilmiş çoğaltılmış polimorfik diziler) markırına çevrilerek (SCAC 568$)$, markır yardımıyla ıslah (MAS) çalışmalarında kullanılmaya başlanmıştır (Çelik ve ark. 2018). Araştırıcılar SCAR makırına ait PCR emplikonlarının XbaI, TaqI, veya HaeIII emzimleri ile elde edilen kesim ürünlerinin TSWV'ye dayanıklı ve hassas genotiplerin belirlenmesinde farklı genetik arka plana sahip genotiplerde başarı ile kullanılabileceğine işaret etmişlerdir (Moury ve ark. 2000). Ancak, SCAC568 + XbaI markırı ile tarafımızda yapılan bazı moleküler testleme sonuçlarında farklı dayanıklılık kaynakları kullanılarak geliştirilmiş F2 popülasyonuna ait bireylerde beklenen açllımın (1RR:2Rr:1rr) elde edilemediği, heterozigot ve homozigot bireylerin kesin olarak ayırt edilmesinde bazı güçlüklerin var olduğu belirlenmiştir.

$\mathrm{Bu}$ çalışmada farklı iki genetik kaynaktan oluşturulmuş iki F2 popülasyonuna ait genotiplerinden elde edilen DNA ile SCAC 568 primeri kullanılarak elde edilen PCR ürünleri ayrı ayrı hem XbaI ile hem de TaqI enzimi ile kesilmiş ve iki kesim sonucu karşılaştırılarak birlikte değerlendirilmiştir.

\section{Materyal ve Yöntem}

Çalı̧̧ma materyali olarak iki farklı dayanıklı F1 (Rr) kaynağı kullanılarak elde edilen iki biber (Capsicum annum) popülasyonun (Popülasyon I ve Popülasyon II) F2 bireyleri kullanılmıştır. Popülasyon I'den 52 ve popülasyon II'den 58 adet olmak üzere toplam $110 \mathrm{~F} 2$ bitkisinin yaprak örneklerinden CTAB protokolü (Doyle ve Doyle 1987) uygulanarak DNA izolasyonu yapılmıştır. DNA örnekleri agaroz jelde yürütülerek kalite kontrolü ve konsantrasyon eşitlemesi yapıldıktan sonra Moury ve ark. (2000) tarafindan geliştirilmiş CAPS markırı (SCAC568) kullanılarak PCR reaksiyonu gerçekleştirilmiştir.
Reaksiyonda 20-30 ng $\mu \mathrm{l}^{-1}$ genomik DNA, $1.5 \mu \mathrm{l} 10 \times \mathrm{PCR}$ buffer, $1 \mu \mathrm{l} 2.5 \mathrm{mM}$ dNTP karışımı, $2 \mu 125 \mathrm{mM} \mathrm{MgCl}_{2}$, ileri (5' GTGCCAGAGGAGGATTTAT 3') ve geri (5', GCGAGGTGGACACTGATAC 3') primerlerin (10 pmol $\left.\mu \mathrm{l}^{-1}\right)$ her birinden $1 \mu \mathrm{l}$ ve $0.08 \mu \mathrm{l}\left(5 \mathrm{U}^{-1} \mathrm{l}^{-1}\right)$ Taq polymerase enzimi içeren karışım kullanılmıştır. PCR cihazında (MyGenie 96Bioneer) döngü protokolü 3 dakika başlangıç denatürasyonu, 35 döngü $95^{\circ} \mathrm{C}$ 'de 50 saniye denatürasyon, $57^{\circ} \mathrm{C}$ 'de 45 saniye bağlanma, $72{ }^{\circ} \mathrm{C}$ 'de 50 saniye uzama, bunu takiben $72{ }^{\circ} \mathrm{C}$ 'de 10 dakika son uzama şeklinde uygulanmıştır. PCR ürünlerinin teyidi amacıyla \% 1.5'luk agaroz jelde ayrıştırılmış ve etidyum bromid ile boyanan jel ultraviyole transillüminatörde görüntülenmiştir. Daha sonra her bir F2 materyalinden elde edilen PCR ürünü XbaI ya da TaqI enzimleri ile ayrı tüplerde kesim işlemine alınmıştır. Bu aşamada, PCR ürünün $7 \mu$ 'si bir

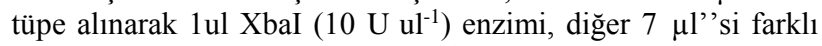
bir tüpe alınarak ul TaqI (10 $\left.\mathrm{U} \mathrm{ul}^{-1}\right)$ enzimi eklenmiş ve her iki tüpe $1 \mu \mathrm{l} 10 \mathrm{X}$ kesim tamponu ve $2 \mu 1$ nükleaz içermeyen steril su eklendikten sonra XbaI enzimi ile kesim için $37^{\circ} \mathrm{C}$ 'de ve TaqI enzimi için ise $65^{\circ} \mathrm{C}$ 'de 2 saat inkübasyona bırakılmıştır. Kesim sonrası elde edilen ürünler \% 2'lik agaroz jel elektroforezinden sonra ultraviyole transilüminatörde görüntülenmiştir.

\section{Bulgular ve Tartışma}

SCAC568 primeri ile yapılan PCR reaksiyonu sonuçları her iki popülasyona ait genotoiplerde 568 bç büyüklüğünde DNA amplifikasyonun var olduğunu göstermiştir (Şekil 1). Popülasyon I'e ait olan 52 F2 bitkisinden elde edilen PCR ürünleri her genotip için ayrı tüplerde olacak şekilde XbaI ve TaqI enzimleri ile kesilmiştir. XbaI enzimi ile yapılan kesim reaksiyonu sonuçları dayanıklı homozigot (RR) genotiplerin PCR ürünlerinin büyük oranda kesilerek agaroz jelde yaklaşık $280 \mathrm{bç}$ uzunluğunda tek bant görüntüsü oluştururken, heterozigot genotiplerde $(\mathrm{Rr})$ kesilen ve kesilmeyen ürünlerin oluşturduğu iki bant ( $280 \mathrm{bç} \mathrm{ve} 568 \mathrm{bç})$ görüntülenmiş ve hassas genotiplerde (rr) ise elde edilen PCR ürünü kesime uğramayarak 568bç büyüklüğünde tek bant belirlenmiştir (Şekil 2a). Popülasyon I'e ait 52 adet F2 bitkisinin TaqI enzimi ile yapilan kesim işlemi sonucunda homozigot dayanıklı (RR) bireylerin PCR ürünleri (568bç) kesime uğramazken, homozigot hassas (rr) bireylerde PCR ürünü tamamı ile kesilerek yaklaşı 230 ve 330 bç büyüklügünde ürünlere dönüşmüştür (Şekil 2). Heterozigot bireylerde hassas allel kesime uğrayarak 2 band (230bç ve $330 \mathrm{bç)}$ oluştururken, dayanıklı allel kesilmeyerek 568bç büyüklügünde kalmış ve agaroz jelde toplam 3 DNA bandı olarak görüntülenmiştir (Şekil 2b). Popülasyon I'de her iki enzimle ayrı ayrı yapılan kesim sonuçları birbiri ile ve SCAC 568 markırının geliştirildiği (Moury ve ark. 2000) çalışma sonuçları ile tam olarak uyumlu bulunmuştur. Ayrıca, F2 bireylerinin 26'sının heterozigot dayanıklı (Rr), 14 tanesinin homozigot dayanıklı (RR) ve 12 örneğin ise hassas (rr) sonuç üretmesi tipik bir F2 popülasyonunda beklenen 1:2:1 aç1lımı ile de örtüşmektedir $\left(x^{2}=0.15 ; \mathrm{p}<0.05\right)$ (Çizelge 1).

Popülasyon II'de test edilen 58 F2 genotipinin 56 adetinden PCR ürünü elde edilmiştir. Bu 56 genotipe ait ürünlerin XbaI enzimi ile yapılan kesim analizi sonucunda, 11 adet hassas (rr) bireye ait PCR ürününün beklendiği şekilde kesime uğramadığ 1 görülmüştür (Şekil 3a). Ancak, geri kalan tüm F2 bireylerinin (45 adet) profili ise tamamı ile heterozigot bir bireyden beklenen profil ile uyum göstermiş olup, bu popülasyondan homozigot dayanıklı (RR) jel profili elde edilememiştir (Şekil 3a). Dolayısı ile, popülasyon II'de XbaI 


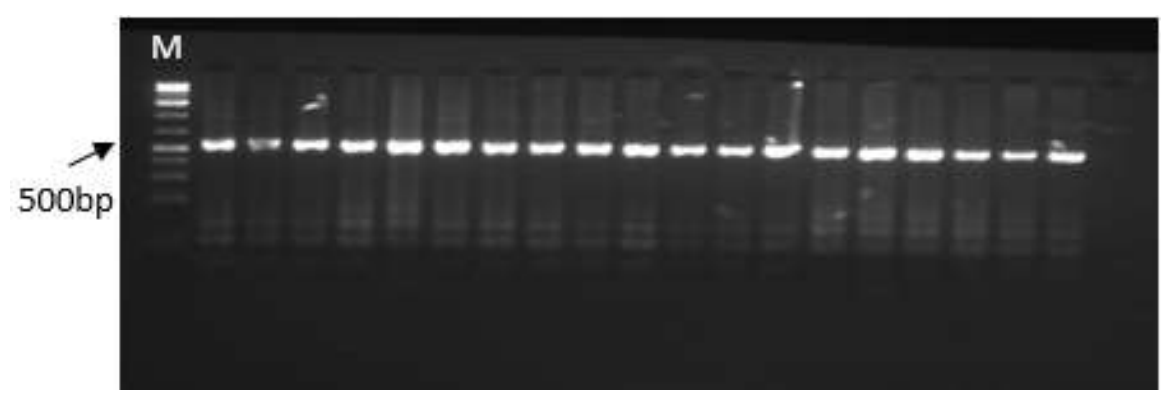

Şekil 1. Bazı F2 genotiplerinde $\mathrm{SCAC}_{568}$ primeri ile yapılan $\mathrm{PCR}$ reaksiyonu sonucu elde edilen 568 bp'lik ürünlere ait örnek jel görüntüsü. M: $1 \mathrm{~kb}$ DNA.

Figure 1. The gel picture of 568 bp PCR product obtained with SCAC568 primer M: 1 kb DNA.
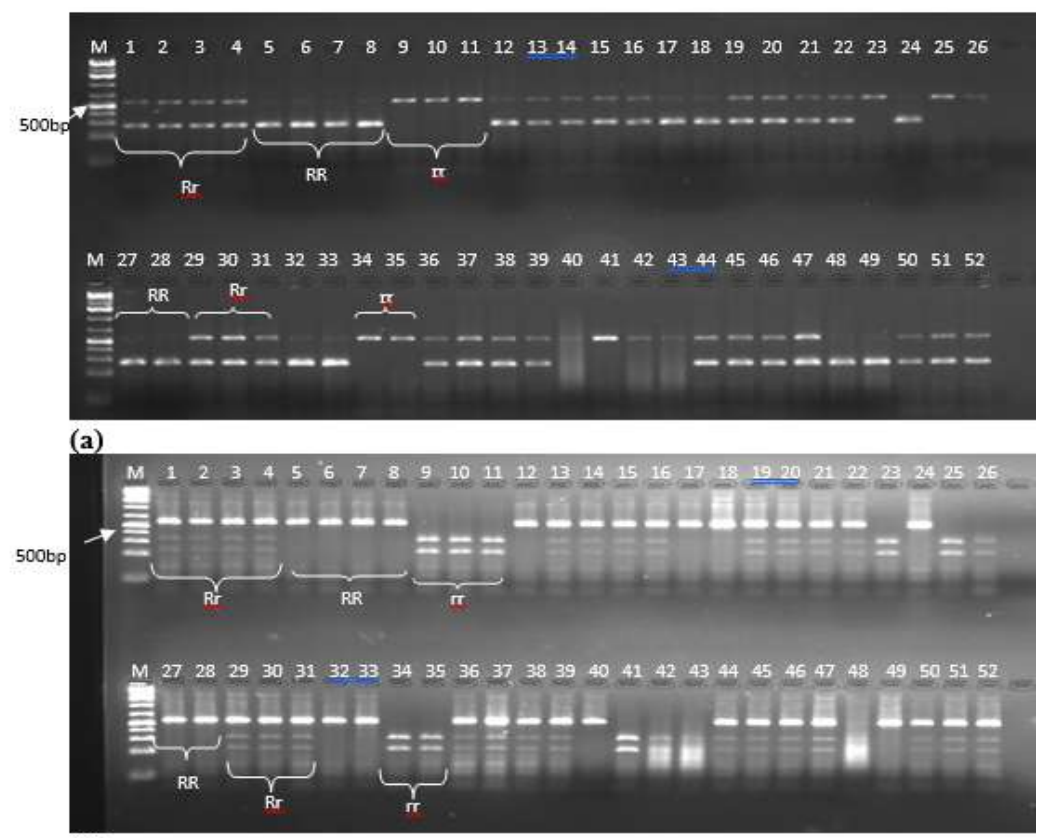

(b)

Şekil 2. Popülasyon I'e ait 52 örneğin PCR ürünlerinin iki farklı enzim ile kesimi sonucu elde edilen jel görüntüsü. (a) XbaI enzimi ile kesilmiş ürünler, (b) TaqI enzimi ile kesilmiş ürünler, M: 1 kb DNA, RR: dominant homozigot, Rr: heterozigot, rr: resessif homozigot genotipler.

Figure 2. The gel picture of digested PCR product of 52 samples belonging to Population I; using two different enzymes, a: The digested fragments with Xbal enzyme, $b$ : The digested fragments with Taql enzyme. M: 1 kb DNA, RR: dominant homozygote, Rr: heterozygote rr: recessive homozygote genotypes.

Çizelge 1. PCR ürünlerinin XbaI ve TaqI enzimi ile yapılan kesim sonuçları (Popülasyon I).

Table 1. The result of PCR products digested with Xbal and Taql enzymes (Population I).

\begin{tabular}{|c|c|c|c|c|c|c|c|c|}
\hline Sample No & XbaI & TaqI & Sample No & XbaI & TaqI & Sample No & XbaI & TaqI \\
\hline 1 & $\mathrm{Rr}$ & $\mathrm{Rr}$ & 19 & $\mathrm{Rr}$ & $\mathrm{Rr}$ & 37 & $\mathrm{Rr}$ & $\mathrm{Rr}$ \\
\hline 2 & $\mathrm{Rr}$ & $\mathrm{Rr}$ & 20 & $\mathrm{Rr}$ & $\mathrm{Rr}$ & 38 & $\mathrm{Rr}$ & $\mathrm{Rr}$ \\
\hline 3 & $\mathrm{Rr}$ & $\mathrm{Rr}$ & 21 & $\mathrm{Rr}$ & $\mathrm{Rr}$ & 39 & $\mathrm{Rr}$ & $\mathrm{Rr}$ \\
\hline 4 & $\mathrm{Rr}$ & $\mathrm{Rr}$ & 22 & $\mathrm{Rr}$ & $\mathrm{Rr}$ & 40 & $?^{*}$ & $\mathrm{RR}$ \\
\hline 5 & RR & RR & 23 & $\mathrm{rr}$ & $\mathrm{rr}$ & 41 & $\mathrm{rr}$ & $\mathrm{rr}$ \\
\hline 6 & RR & RR & 24 & RR & $\mathrm{RR}$ & 42 & $\mathrm{rr}$ & $\mathrm{rr}$ \\
\hline 7 & RR & RR & 25 & $\mathrm{rr}$ & $\mathrm{rr}$ & 43 & $\mathrm{rr}$ & $\mathrm{rr}$ \\
\hline 8 & RR & RR & 26 & $\mathrm{rr}$ & $\mathrm{rr}$ & 44 & $\mathrm{Rr}$ & $\mathrm{Rr}$ \\
\hline 9 & $\mathrm{rr}$ & $\mathrm{rr}$ & 27 & $\mathrm{RR}$ & $\mathrm{RR}$ & 45 & $\mathrm{Rr}$ & $\mathrm{Rr}$ \\
\hline 10 & $\mathrm{rr}$ & $\mathrm{rr}$ & 28 & RR & $\mathrm{RR}$ & 46 & $\mathrm{Rr}$ & $\mathrm{Rr}$ \\
\hline 11 & $\mathrm{rr}$ & $\mathrm{rr}$ & 29 & $\mathrm{Rr}$ & $\mathrm{Rr}$ & 47 & $\mathrm{Rr}$ & $\mathrm{Rr}$ \\
\hline 12 & $\mathrm{RR}$ & $\mathrm{RR}$ & 30 & $\mathrm{Rr}$ & $\mathrm{Rr}$ & 48 & $\mathrm{RR}$ & $?^{*}$ \\
\hline 13 & $\mathrm{Rr}$ & $\mathrm{Rr}$ & 31 & $\mathrm{Rr}$ & $\mathrm{Rr}$ & 49 & $\mathrm{RR}$ & $\mathrm{RR}$ \\
\hline 14 & $\mathrm{Rr}$ & $\mathrm{Rr}$ & 32 & RR & $\mathrm{RR}$ & 50 & $\mathrm{Rr}$ & $\mathrm{Rr}$ \\
\hline 15 & $\mathrm{Rr}$ & $\mathrm{Rr}$ & 33 & RR & $\mathrm{RR}$ & 51 & $\mathrm{Rr}$ & $\mathrm{Rr}$ \\
\hline 16 & $\mathrm{Rr}$ & $\mathrm{Rr}$ & 34 & $\mathrm{rr}$ & $\mathrm{rr}$ & 52 & $\mathrm{Rr}$ & $\mathrm{Rr}$ \\
\hline 17 & RR & $\mathrm{RR}$ & 35 & $\mathrm{rr}$ & $\mathrm{rr}$ & & & \\
\hline 18 & RR & $\mathrm{RR}$ & 36 & $\mathrm{Rr}$ & $\mathrm{Rr}$ & & & \\
\hline
\end{tabular}

*; Belirsiz sonuç. *; Ambiguous results. 
enzimi ile elde edilecek sonuçlar yalnızca dayanıklı ve hassas bireyleri güvenilir bir şekilde ayırırken, $\mathrm{RR}$ ve $\mathrm{Rr}$ profilini ayıramamaktadır (Çizelge 2). Testleme sonucu elde edilen 3:1 açılım oranı, tipik bir F2 popülasyonunda kodominant bir markırdan beklenen oran $(1: 2: 1)$ ile uyumsuz olup $\left(x^{2}=24.96\right.$; p>0.05), ancak dominant bir markırdan elde edilecek sonuçlar ile uyum gösterebilir $\left(\mathrm{x}^{2}=0.85 ; \mathrm{p}<0.05\right)$, Oysa, popülasyon I'den elde edilen sonuçlar ve Moury ve arkadaşlarının (2000) çalışma sonuçları $\mathrm{SCAC}_{568}$ lokusunun ko-dominant bir markır olduğunu gösterirken farklı bir genetik arka plana sahip popülasyon II genotipleri için dominant markır özelliği göstermiştir.
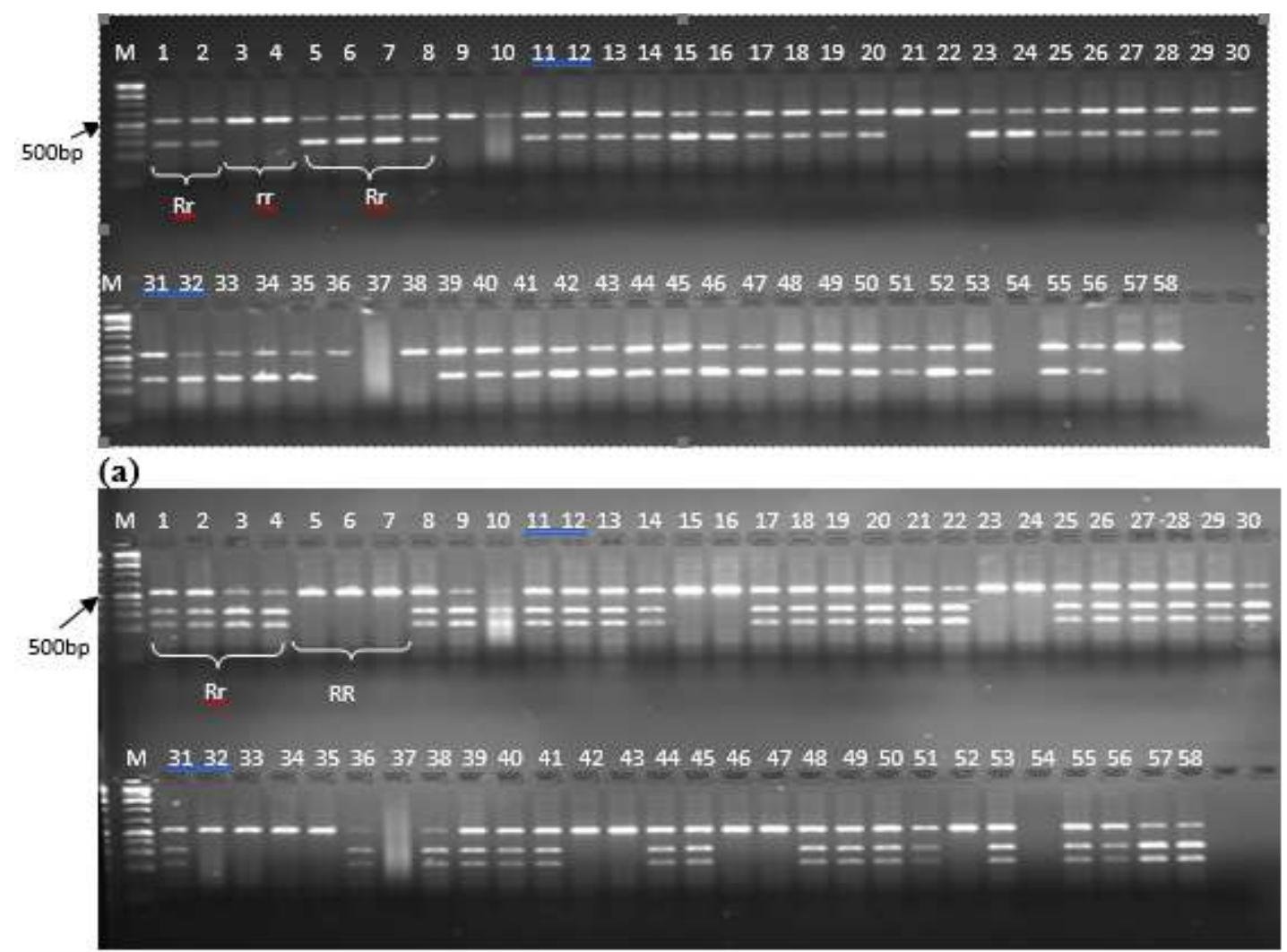

(b)

Şekil 3. Populasyon II’e ait 58 örneğin (56 tanesinde ürün elde edilmiş) PCR ürünlerinin iki farklı enzim ile kesimi sonucu elde edilen jel görüntüsü. (a) XbaI enzimi ile kesilmiş ürünler, (b) TaqI enzimi ile kesilmiş ürünler, M: 1 kb DNA.

Figure 3. The gel picture of digested PCR product of 58 samples ( 56 samples amplified) belonging to Population Il using two different enzymes, a: The digested fragments with Xbal enzyme, b: The digested fragments with Taql enzyme. M: 1 kb DNA.

Çizelge 2. PCR ürünlerinin XbaI ve TaqI enzimi ile yapılan kesim sonuçları (Popülasyon II).

Table 2. The result of PCR products digested with Xbal and Taql enzymes (Population II).

\begin{tabular}{|c|c|c|c|c|c|c|c|c|}
\hline Sample No & XbaI & TaqI & Sample No & $\mathrm{XbaI}$ & TaqI & Sample No & $\mathrm{XbaI}$ & TaqI \\
\hline 1 & $\mathrm{Rr}$ & $\mathrm{Rr}$ & 21 & $\mathrm{Rr}$ & $\mathrm{Rr}$ & 41 & $\mathrm{Rr}$ & $\mathrm{Rr}$ \\
\hline 2 &. $\mathrm{Rr}$ & $\mathrm{Rr}$ & 22 & $\mathrm{Rr}$ & $\mathrm{Rr}$ & 42 & $\mathrm{Rr}$ & RR \\
\hline 3 & $\mathrm{rr}$ & $\mathrm{Rr}$ & 23 & $\mathrm{Rr}$ & RR & 43 & $\mathrm{Rr}$ & RR \\
\hline 4 & $\mathrm{rr}$ & $\mathrm{Rr}$ & 24 & $\mathrm{Rr}$ & RR & 44 & $\mathrm{Rr}$ & $\mathrm{Rr}$ \\
\hline 5 & $\mathrm{Rr}$ & RR & 25 & $\mathrm{Rr}$ & $\mathrm{Rr}$ & 45 & $\mathrm{Rr}$ & $\mathrm{Rr}$ \\
\hline 6 & $\mathrm{Rr}$ & RR & 26 & $\mathrm{Rr}$ & $\mathrm{Rr}$ & 46 & $\mathrm{Rr}$ & RR \\
\hline 7 & $\mathrm{Rr}$ & RR & 27 & $\mathrm{Rr}$ & $\mathrm{Rr}$ & 47 & $\mathrm{Rr}$ & RR \\
\hline 8 & $\mathrm{Rr}$ & $\mathrm{Rr}$ & 28 & $\mathrm{Rr}$ & $\mathrm{Rr}$ & 48 & $\mathrm{Rr}$ & $\mathrm{Rr}$ \\
\hline 9 & $\mathrm{rr}$ & $\mathrm{Rr}$ & 29 & $\mathrm{Rr}$ & $\mathrm{Rr}$ & 49 & $\mathrm{Rr}$ & $\mathrm{Rr}$ \\
\hline 10 & $\mathrm{rr}$ & $\mathrm{Rr}$ & 30 & $\mathrm{rr}$ & $\mathrm{Rr}$ & 50 & $\mathrm{Rr}$ & $\mathrm{Rr}$ \\
\hline 11 & $\mathrm{Rr}$ & $\mathrm{Rr}$ & 31 & $\mathrm{Rr}$ & $\mathrm{Rr}$ & 51 & $\mathrm{Rr}$ & $\mathrm{Rr}$ \\
\hline 12 & $\mathrm{Rr}$ & $\mathrm{Rr}$ & 32 & $\mathrm{Rr}$ & RR & 52 & $\mathrm{Rr}$ & RR \\
\hline 13 & $\mathrm{Rr}$ & $\mathrm{Rr}$ & 33 & $\mathrm{Rr}$ & RR & 53 & $\mathrm{Rr}$ & $\mathrm{Rr}$ \\
\hline 14 & $\mathrm{Rr}$ & $\mathrm{Rr}$ & 34 & $\mathrm{Rr}$ & RR & 54 & $?^{*}$ & $?^{*}$ \\
\hline 15 & $\mathrm{Rr}$ & RR & 35 & $\mathrm{Rr}$ & RR & 55 & $\mathrm{Rr}$ & $\mathrm{Rr}$ \\
\hline 16 & $\mathrm{Rr}$ & RR & 36 & $\mathrm{rr}$ & $\mathrm{Rr}$ & 56 & $\mathrm{Rr}$ & $\mathrm{Rr}$ \\
\hline 17 & $\mathrm{Rr}$ & $\mathrm{Rr}$ & 37 & $?^{*}$ & ?* & 57 & $\mathrm{rr}$ & $\mathrm{Rr}$ \\
\hline 18 & $\mathrm{Rr}$ & $\mathrm{Rr}$ & 38 & $\mathrm{rr}$ & $\mathrm{Rr}$ & 58 & $\mathrm{rr}$ & $\mathrm{Rr}$ \\
\hline 19 & $\mathrm{Rr}$ & $\mathrm{Rr}$ & 39 & $\mathrm{Rr}$ & $\mathrm{Rr}$ & & & \\
\hline 20 & $\mathrm{Rr}$ & $\mathrm{Rr}$ & 40 & $\mathrm{Rr}$ & $\mathrm{Rr}$ & & & \\
\hline
\end{tabular}

*; Belirsiz sonuç. *; Ambiguous results. 
Popülasyon II'de test edilen ayn 1 genotiplere ait PCR ürünleri, Taq I enzimi ile kesime tabii tutularak uyumsuzluğun sebebi araştırılmış ve sonuçlar agaroz jelde incelenmiştir (Şekil 3b). TaqI kesim sonuçları incelendiğinde, XbaI kesim enzimi sonuçlarının 45 adet F2 genotipinden 16'sının dominant homozigot dayanıklı genotip olduğunu (568bç kesilmemiş PCR ürünü) geri kalan $40 \mathrm{~F} 2$ genotipinin ise heterozigot $(\mathrm{Rr})$ bireyler olduğunu göstermiştir (Şekil 3b). Bu durum SCAC568 markırının bazı biber genotiplerinde dominant davrandığ sonucunu teyit etmektedir. Sonuçlar, TaqI kesim sonucu heterozigot bir bireyden beklenen profil ile tam uyumlu olup, daha önce XbaI kesimi ile hassas (rr) oldukları belirlenen 11 genotip dahil hiçbir genotip hassas profil göstermemiştir (Şekil $2 \mathrm{~b}$ ve $3 \mathrm{~b}$ ). Bu durum, TaqI kesim sonuçları (16RR: 40Rr) popülasyon II'de yalnızca dayanıklı birey genotip varlığını ortaya koyarak hatalı sonuçlar üretmekte ve tipik bir geri melez islah programında hassas bireylerin heterozigot dayanıklı olarak yorumlanmasina yol açabilecek sonuçlar üretmektedir.

Dayanıklılık ıslahı çalışmalarında dayanıklı ve hassas bitkilerin doğru bir şekilde seleksiyonu en önemli basamaktır ve çok sayıda ıslah materyalinin kısa sürede ve güvenilir, bir yöntemle test edilmesi amaçlanır. Bu nedenle farklı ürünlerde önemli hastalıkların dayanıklılık genleri ile ilişkili markır geliştirme çalışmaları tüm dünyada yaygın olarak yürütülmekte ve mevcut markırlara yenileri eklenmektedir (Moury ve ark. 2000; Shi ve ark. 2011; Yang ve ark. 2012; Nevame ve ark. 2018). Dayanıklılık geni/genleri ile ilgili markır geliştirme çalışmalarında genellikle yabani genetik kaynaklara ihtiyaç duyulmaktadır. Bazen birden fazla yabani genotip dayanıklılık gen/ genlerin kaynağı olarak kullanılabilmektedir. Bu durum da bir genetik kaynaktan gelen dayanıklılık geni için geliştirilmiş markırın başka bir kaynaktan elde edilen dayanıklılık geninin belirlenmesinde etkin olarak çalışamayacağına işaret etmektedir. $\mathrm{Bu}$ çalışmada biberde TSWV dayanıklılık geni (Tsw) için Moury ve ark. (2000) tarafından geliştirilmiş CAPS markırı farklı genetik kaynaklardan oluşturulmuş iki farklı F2 biber popülasyonunda test edilmiştir. SCAC568 primeri (Moury ve ark. 2000) ile elde edilen PCR ürünleri iki farklı enzim ile kesilerek sonuçlar değerlendirilmiştir. Popülasyon I'in PCR ürünleri hem XbaI ile hem de TaqI ile kesildiğinde her iki enzimin kesim sonuçları tek başına dayanıklı ve hassas bireyleri ko-dominant seviyede ayırt edebilirken, diğer popülasyonda (popülasyon II) F2 genotiplerinin ko-dominant seviyede ayırt edilebilmesi için her iki enzimle yapılan kesim sonuçlarının birlikte karşılaştırmalı olarak değerlendirilmesi gerektiğini göstermiştir. Popülasyon II'de homozigot dayanıklı genotipler (RR) TaqI enzim kesim sonuçları, hassas genotipler (rr) ise XbaI enzim kesim sonuçları ile doğru olarak değerlendirilmiştir. Bunun dışında, kalan genotipler ise her iki kesim enzimi sonucunda da heterozigot profili ürettiği için doğru bir şekilde tanımlanabilmiştir.

\section{Sonuç}

$\mathrm{Bu}$ çalışmada farklı genetik kaynaklardan elde edilmiş F2 biber genotiplerinde $\mathrm{SCAC}_{568}$ markırının PCR ürünleri XbaI ve TaqI enzimleri ile ayrı ayrı kesilerek kesim ürünlerinin TSWV'ye dayanıklı ve hassas genotiplerin belirlenmesindeki etkinlikleri belirlenmeye çalışılmıştır. Çalışma sonuçları faklı genetik arka plana sahip bitkilerde XbaI enzimi ile yapılan kesimlerin dayanıklı genotipleri dominant düzeyde doğru bir şekilde belirleyebildiği, TaqI kesim sonuçlarının ise aynı genotiplerde hatalı sonuçlar üretebildiğini göstermiştir. Sonuçlar aynı zamanda TSWV'ye karşı dayanıklılık için farklı allel formlarının farklı genetik arka planlarda var olabileceğini ve markıra dayalı seleksiyon yapılabilmesi için SCAC 568 lokusunun PCR amplifikasyonu sonrası XbaI and TaqI enzimlerine ait kesim sonuçlarının karşılaştırmalı olarak birlikte değerlendirilmesinin gerekli olduğunu göstermiştir.

\section{Teşekkür}

Bu çalışmada kullanılan laboratuvar altyapı desteği için Akdeniz Üniversitesi, Ziraat Fakültesine teşekkür ederiz.

\section{Kaynaklar}

Azeri T (1994) Detection of tomato spotted wilt virus in tobacco and tomato cultivars by enzyme linked immunosorbent assay. J. Turkish Phytopathology 23(1): 37-46.

Black LL, Hobss HA, Gatti JM (1991) Tomato spotted wilt virus resistance in Capsicum chinense 'PI 152225'and 'PI 159236'. Plant Disease, 75: 863.

Boiteux LS (1995) Allelic relationships between genes for resistance to tomato spotted wilt tospovirus in Capsicum chinense. Theorotical and Applied Genetics 90: 146-149.

Brittlebank CC (1919) Tomato diseases. Journal of Agriculture Victoria 27: 231-235.

Cebolla-Cornejo J, Soler S, Gomar B, Soria DM, Nuez F (2003) Screening Capsicum germplasm for resistance to tomato spotted wilt virus (TSWV). Annals of Applied Biology 143(2): 143-152.

Costa J, Catalá MS, Lacasa A, Díez MJ, Nuez F (1995) Introduction of plant genetic resistance to TSWV from C. chinense 'PI 159236' in different pepper genetic backgrounds. In First International Symposium on Solanacea for Fresh Market. March 28-31 1995, Malaga, Spain. Acta Hortic. 412: 523-532.

Çelik İ, Özalp R, Çelik N, Polat İ (2018) Domates Lekeli Solgunluk Virüsü (TSWV)'ne dayanıklı sivri biber hatlarının Geliştirilmesi. Derim 35(1): 27-36 doi: 10.16882/derim.2018.325765.

Doyle JJ, Doyle JL (1987) A rapid DNA isolation procedure for small quantities of fresh leaf tissue. Phytochem Bull 19: 11-15.

Floor HH (1971) Current status of the gene-for-gene concept. Annual Reviews of Phytopathology 9: 275-296.

German TL, Ullman DE, Moyer JW (1992) Tospoviruses: diagnosis, molecular biology, phylogeny, and vector relationships. Annual Review of Phytophatology 30, 315-348.

Goldbach R, Peters D (1994) Possible causes of the emergence of tospovirus diseases. Sem. Virology. 5: 113-120.

Jahn M, Paran I, Hoffmann K, Radwanski ER, Livingstone KD, Grube RC, Aftergoot E, Lapidot M, Moyer J (2000) Genetic mapping of the Tsw locus for resistance to the tospovirus tomato spotted wilt virus in Capsicum spp. and its relationship to the Sw-5 gene for resistance to the same pathogen in tomato. The American Phytopathological Society 13(6): 673-682.

Moury B, Palloix A, Gebre Selassie K, Marchoux G (1997) Hypersensitive resistance to tomato spotted wilt virus in three Capsicum chinense accessions is controlled by a single gene and is overcome by virulent strains. Euphytica 94: 45-52.

Moury B, Pflieger S, Blattes A, Lefebvre V, Palloix A (2000) A CAPS marker to assist selection of tomato spotted wilt virus (TSWV) resistance in pepper. Genome 43: 137-142.

Nevame AYM, Xia L, Nchongboh CG, Hasan MM, Alam MA, Yongbo, L Wenting Z, Yafei H, Emon RM, İsmail MR, Efisue A, Gang S, Wenhu L, Longting S (2018) Development of a New Molecular Marker for the Resistance to Tomato Yellow Leaf Curl Virus, BioMed Research International, vol. 2018, Article ID 8120281, https://doi.org/10.1155/2018/8120281. 
Parrella G, Gognalons P, Gebre-Selassie K, Vovlas C, Marchoux G (2003) An update of the host range of Tomato spotted wilt virüs. Journal of Plant Pathology 8: 227-264.

Rosello S, Diez MJ, Lacasa A, Jorda C, Nuez F (1996) Testing resistance to TSWV introgressed from Lycopersicon peruvianum by artificial transmission techniques. Euphytica 98: 93-98.

Shi A, Vierling R, Grazzini R, Chen P, Caton H, Panthee D (2011) Identification of molecular markers for $\mathrm{Sw}-5$ gene of tomato spotted wilt virus resistance. Am. J Biotechnol. Mol. Sci. 1: 8-16 doi: 10.5251/ajbms.2011.1.1.8.16.

Tekinel N, Dolar MS, Sağsöz S, Salcan Y (1969) Mersin Bölgesinde ekonomik bakımdan önemli bazı sebzelerin virüsleri üzerinde araştırmalar. Bitki Koruma Bülteni 9(1): 37-49.
Tekinel N (1973) Adana, Antalya, Hatay ve İçel illerinde domates virüs hastalıklarının yayılış alanlarının ve oranlarının tespiti üzerinde araştırmalar. Bitki Koruma Bülteni Cilt 13 No: 3, s. 107-141.

Yang HB, Liu WY, Kang WH, Kim JH, Cho HJ, YooJH, Kang BC (2012) Development and validation of L allele-specific markers in Capsicum. In Molecular Breeding vol. 30, no. 2, pp. 819-829. doi: 10.1007/s11032-011-9666-7.

Yürtmen M, Guldur ME, Yılmaz MA (1999) Tomato spotted wilt virus on peppers in İçel province of Turkey. Petria 9(3): 243-344. 